\title{
New Urbanism and the City Planning (Implications of the Application of the New Urbanism Principles on the Land Uses in Al-Karkh in Baghdad City)
}

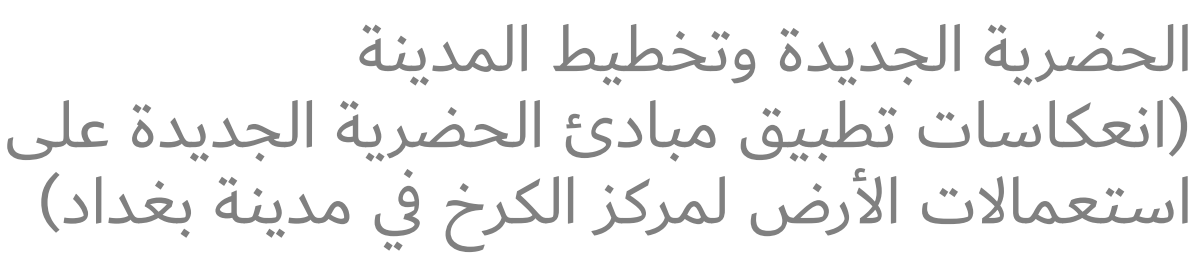

Nida Hussein Abid Aown ${ }^{1}$ and Hala Ali Meer ${ }^{2}$

نداء حسين عبد عون وهالة علي مير

${ }^{1}$ Design Department, Mayoralty of Baghdad, Baghdad, Iraq

${ }^{2}$ Student; PhD, Urban \& Regional Planning Center for Postgraduate Studies, Baghdad, Iraq

Corresponding Author: Nida Hussein Abid Aown nidahussein@yahoo.com

Received: 28 December 2017 Accepted: 2 February 2018

Published: 1 May 2018

Publishing services provided by Knowledge E

(c) Nida Hussein Abid Aown and Hala Ali Meer. This article is distributed under the terms of the Creative Commons

Attribution License, which permits unrestricted use and redistribution provided that the original author and source are credited.

Selection and Peer-review under the responsibility of the Urban Planning Iraq Conference Committee.

\section{Abstract}

Over the past 60 years, towns and cities were under a great transformation. The city has become less defined through its physical boundaries with a development of suburban area with a huge number of separate houses. The City is the essence of our civilization and it provides a frame for social life. Gardens, streets planner, and yard brings people together well and gives them a chance of social encounters, which have economic also. Friendly and beautiful cities can bring life insurance to people in urban areas.

The "New Urbanism" is the most influential planning movements since the late twentieth century. The planning ideas and successful projects of new urbanism lead us to better living conditions. Under the influence of globalization, the urban construction of cities inevitably influenced by the impact of new ideas and at the same time, during the process of construction emerged some urban problems.

Activities in the city need a particular place or space that can be done by the coordinate of that space. The place or the land is the most important factor in shaping the physical environment and the context of urban activities. It has always been regarded as a base for urban construction by planners. Planning of land use "as the core of urban planning" plays an important role in the spatial and temporal organization of cities. The study of new urbanism principles in land use planning in urban areas is based on its benefits on planning at all levels of the study of human communities of mass and streets in the regions and cities. Over the past decades, the city of Baghdad has grown rapidly in a random and uncontrolled way and a kind of unsustainable urbanization has taken place.

\section{G OPEN ACCESS}


The objective of the research was to analyze the land use for the Center of Al-Karkh in Baghdad city from the standpoint of the new urbanism using qualitative and quantitative study of the land uses, and the application of the principles of the new urbanism theory to achieve the appropriate model by descriptive and analytical approach. The necessary data had been collected for this research by the office and media research having to do with the above subject,and it will adopt the statistical community of this research for a sample of the population of Al-Karkh center to gain access to the results of this research.

The results of this study showed that the per capita ratios in the uses of land in the city of Al-Karkh were not based on the new urbanism perspective and in the spatial distribution of land uses, and human orientation and the people were not satisfied with the possibility of land use in the city of Al-Karkh..

كانت المدن والبلدات على مدى السنوات الستين الماضية، تحت ظل تحولات وتطورات كبيرة، فلقد

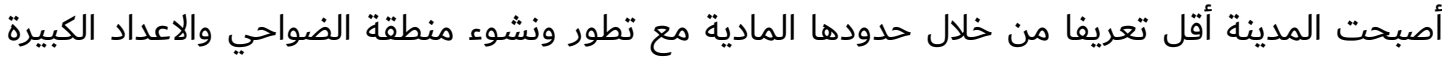
من المنازل المنفصلة. وتعد المدينة جوهر حضارتنا اذ توفر إطارا للحياة الاقتصادية والاجتماعية ، فمخططات

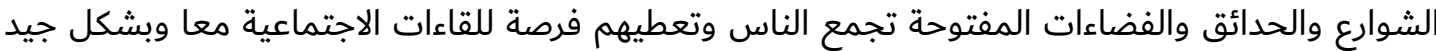
وبذلك يمكن لهذه المدن الودية أن تعطي الامان للأشخاص في المناطق الحضرية.

وتعد الحضرية الجديدة Urbanism "New " من أكثر حركات التخطيط نفوذا وتأثيرا في منذ أواخر القرن

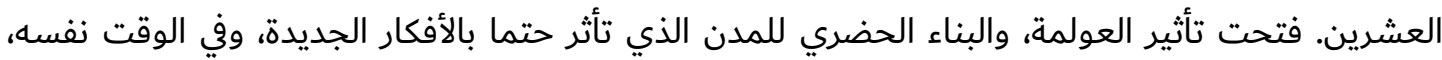

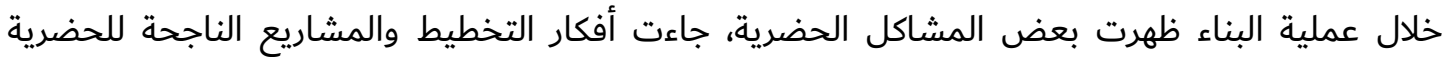
الجديدة التي تقودنا إلى ظروف معيشية أفضل.

ان أي نشاط في المدينة يتطلب مكان أو مساحة معينة، ويمكن أن يتم من خلال تنسيق هذه المساحة، فالمكان او الارض هي العامل الاكثر اهمية في تشكيل البيئة المادية وسياق الانشطة الحضرية اذ اعتبرت دائما كقاعدة للبناء في المناطق الحضرية من قبل المخططين ـ وان تخطيط استعمال الأراضي في المناطق

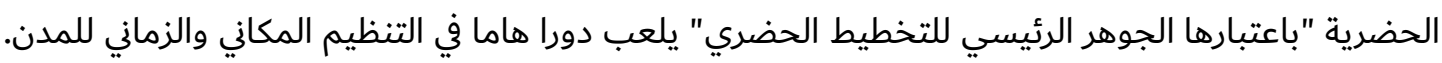
وتعد دراسة مبادئ الحضرية الجديدة في تخطيط استخدام الأراضي في المناطق الحضرية تبعا لفوائده على التخطيط على جميع المستويات من دراسة المجتمعات البشرية من كتلة وشوارع في المنطقة والمدينة. خلال العقود الماضية، نمت مدينة بغداد على نحو سريع بطريقة عشوائية وغير مسيطر عليها وحدث نوع دمات

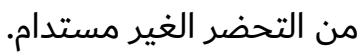

الهدف من هذا البحث هو تحليل استعمالات الأراضي لمركز الكرخ في مدينة بغداد من وجهة نظر الحضرية الجديدة باستخدام الدراسة النوعية والكمية لاستخدامات الأراضي، وتطبيق مبادئ نظرية الحضرية الجديدة

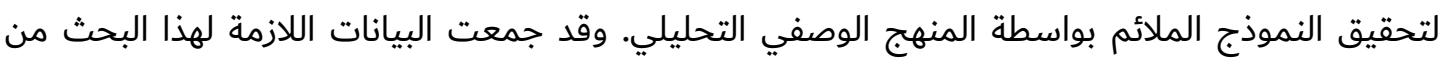

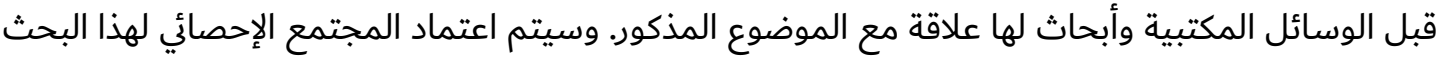


لعينة من سكان مركز الكرخ للوصول الى نتائج لهذا البحث ـ وأظهرت نتائج هذه الدراسة أن نسب الفرد

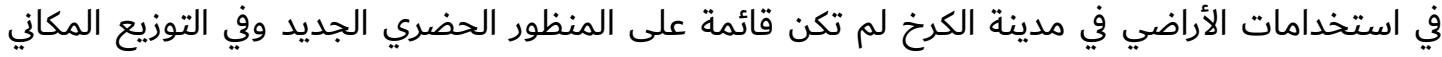
لاستخدامات الأراضي والتوجه البشري ولم يكن الناس راضين عن إمكانية استخدام الأراضي في مدينة الكرخ.

Keywords: The city, Urban land uses, Land uses planning, New urbanism theory.

المدينة، استعمالات الأراضي الحضرية، تخطيط استعمالات الأراضي، نظرية الحضرية

\section{Introduction}

The "New Urbanism "is the most important phenomenon in planning and architecture since the movement of modernity, a movement that encourages ideas that challenge long practices and prioritize the importance of an integrated approach to correct the problems of urban growth and changes in public policies, urban structure and land uses in cities. In recent years, and since the year 1960 and during the year 1980, the adoption of new urbanism principles and the work of planners, architects and designers and academics to gather ideas for new developments, and the increase in the use of private cars, and the lack of diversity in the communities and in the decades that followed world war II. The resulting philosophy, the new urbanism, has become the most influential in the last period of the twentieth century. The Basic question is what the principles of the new urbanism could be applied in the land use of urban areas and how can these principles used for designs and urban planning. In this regard, the study of the new urbanism principles those have been widely used around the world and have been a dramatic success seems to be an imperative. The investigation of different types of land use in urban areas, the proportion of each the land use to the other and the relationship with each other are among the case that is effective in designing and using the physical optimum of the land. The study of each land use in order to achieve appropriate measures and principles of urban planning are one of the most important actions [1]. The study principle of the new urbanism, which has widely used around world and has been very successful, is an imperative [2].

The distributions, selection of space, determination of land use and smooth access to it are unfavorable in the city of Al-Karkh. There are no suitable spaces for the activities of humans in the city of Al-Karkh from a new urban perspective.

The cooperation of the population in assigning the important spaces compatible with their culture is weak. Even this case is not considered in per capita land use for the provision of an appropriate and compatible environment; attention is also paid to 
human and to man-oriented spaces in urban development plans, and their distribution is unconsidered.

The new urbanism, well known for the design of traditional and traditional new areas, is defined as a set of planning principles that give habitable areas and corridors in a pedestrian-friendly environment. The new urbanism is a reaction to the urban proliferation. [3]. It is such an effective way against car-dependent communities where every trip is made by cars [4]. Thus this theory can be exploited to define problems to provide solutions in order to revive the city, to rebuild the suburbs, to protect the natural environment and to enhance the quality of life and its standards. Moreover, this view leads to the prevention of growth and unauthorized construction and excessive city, increased supply of lateral and main streets in central parts of the city, the provision of a garage to reduce traffic, control of legality and raise people's awareness of cooperation, regulation and orientation and provide safety, comfort and well-being for residents of Al-Karkh.

Al-Karkh has faced many challenges in the field of the transportation network and urban construction. One of the very important issues of urban life is the way how land is used. Control of land division is the very effective way to implement the principles of planning and division of cities into residential, industrial, commercial and administrative areas and to implement urban land use rules. The assessment of the division and use of lands can reflect a clear and good picture of the urban view and the distribution of urban space over time to different uses in the city in order to achieve goals of urban development. Global experience generally shows that the success in land use planning in the urban areas depends on cooperation and also the balance between two sets of factors: (a) existence of appropriate policies and rules in land use; (b) use of effective methods in the provision and implementation of urban designs and the use schedule Land [5]. Therefore, for the planning and assessment of urban land use in urban areas, the adequacy of rules and regulations and the use of effective methods are a critical point in the evaluation and planning of land use in urban areas [6]. Despite a new urban movement within the framework of housing development, it has always stressed the development and reform of internal structures. They object to the excessive spread of the city and thus waste the land [7].

In this paper, the following questions addressed: Is the level and individual attributable to Al-Karkh land uses with the theory of new urbanism, and they are the new urbanism principles studied in the studied area?, Is the correlation between land use and orientation of humans in the spatial distribution of land uses in the city of Al-Karkh?, Are people satisfied with the access to land use required in Al-Karkh and 
the location?, Do you look at the new urbanism principles and take them into account effectively to satisfy the population by using land distribution?

\section{The main concepts of research and theoretical literature}

\subsection{CONCEPT}

\subsubsection{The City}

The city is an urban system in a hierarchical order, to gather people, form components, have physical, or symbolic, features to isolate the population from strangers, provide specialization in work, and diversity in capital. Cities are based on administrative and service environments. The cities and cities are also characterized by some of the characteristics of the architectural structure through the presence of public buildings, and thus it is a place composed of a group of people and environments, and the city body and its real function, and the ideas and values that connect people, is one phenomenon.

The City as an Urban Environment The city is an integrated system driven by several secondary systems that are interrelated with each other, resulting in the final form of the city. 1. Structural system. 2. The transportation system includes transportation and communication. 3. Information system. Which contributes to the reduction of time and distance, which changes the way of understanding and understanding of the urban environment? 4. Cognitive systems: Cognitive value systems, which mean the accepted customs and traditions and the religious beliefs of each urban society within cities. 6 - System of decision: Represented by the body with administrative and legislative authority to take various decisions related to the planning and design of urban cities. 6 - Production system: The nature of specialization in the division of production in the urban society of the city between trade and industry and others. [13]

\subsubsection{New urbanism theory}

It is an international movement that began as a reaction to passive investment in city centers, the spread of unplanned spaces, the distinction between the human race, the erosion of the heritage structures of society and the adoption of the new urban constitution by designers and planners all over the world. It's Movement to reform and regulate the design of the urban environment that arises from the characteristic of life, the standard of living, about The way to create the best places to live, and work mainly 
on the reorganization of the built environment, in the form of Harmonious cities, towns, villages, and residential neighborhoods in the same way that communities were built, for several Centuries in multiple regions of the world. [8] The new Urbanism Movement aims to recreate the idea of traditional neighborhood design. The intention of this theory was to create a sense of society and to restore the lost sense of place because of the use of one's current Euclidean land development practices. we can see that the concepts presented by the new urbanism theory, for example, high density, narrow street, growing growth, mixed land use, strong connection to the streets, compact, pedestrian-oriented design, these concepts are important because they encourage the development of a sense of community and provide flexibility and affordability costs, which are needed for the low-income group in the absence of capital investments and resources.

\subsubsection{Urban land uses}

Land use is one of the key areas used for action to improve performance in global sustainable development. The Land allows a variety of uses and can meet a variety of goals. The land uses is an essential element in the human activity much of what we humans require land. [9] Thus, the concept of land uses refers to a series of the activities that are performed to service or generate a product or more. Can use the same land uses on different pieces of land, likewise, it may be the same land several uses. And it provides the activity-based definition of land use, a detailed quantitative analysis of the environmental and economic impacts, and also empowerment of discrimination clearly different land uses. [10]

\subsection{4. land use Planning}

Land use planning is process which the society decides on various economic and social activities, such as agriculture, housing, industry, leisure and trade. This includes protection well-defined areas of development because of Environmental, cultural, historical, or similar reasons, and the development of the provisions that govern the nature of the Developmental activities.

the planning of land use is "systematic assessment of land and water potential, alternative patterns of land use and other physical, social and economic conditions" for the purpose of adopting land and selecting which is the most useful for the land uses without degradation of resources or the environment, use options, along the choice of measures most likely to be encouraged such the land uses" [11] must be" a 
decision process that facilitates allocation of land to the uses that provide the greatest sustainable benefits and to promote the transition to a sustainable and integrated management of land resources". [12]

\subsection{Theoretical and literature}

Land use has been put into planning for the first time in America and Europe with an advent of new urbanization. Initial actions were mostly engineering, legal and administrative. However, since a beginning of 1960, use of urban land in a specific way of land-use planning has been taken seriously on the basis of objective and systematic concepts, rules and methods. The view that the use of urban land doesn't include only administrative,and material issue, but also has environmental economic, cultural and social dimensions. It has been gradually promoted in the western cities. The perspective of the land regulation is secure in order to provide government sovereignty and establish property rights. In the United States of America, the first division law of land was passed in 1885 and initial zoning regulations were implemented in 1922. In the 1980's, a large number of American architects and urban planners were dissatisfied with erosion, the urban center's deterioration and the increase of dispersed and scattered communities, dependent on cars and also far from urban centers. In the last decade of 1980 and also the beginning of 1990, this discontent led to the movement of new urbanism [14]. The use of such a new word and its combination with the term "urbanism" refers to concepts such as energy, freshness, and vitality. This position (presented by planners and urban architects in early 1980) attempted to address the problems of urbanization and rural development after World War II. Rapid urbanization, population growth and migration all lead to overcrowding and hence overcrowding Urban traffic causing land consumption and low vegetation as well Proliferation and urban expansion, which leads to the expansion of infrastructure, and therefore difficult to maintain, because it is not Grouped in specific places, research finds that the solution is in high structural density, and follow City Compact, urban design, service aggregation, and usage (Mixed Use of land), to control infrastructure services, and to create a public transport system as one Sustainable urban mechanisms focusing on characteristics that formed the basis of building neighborhood units which known as traditional physical characteristics, the new urban aims to make use from Traditional urbanization to address the current urban and regional concerns [15]. Researchers have been conducted in the area of land use planning and urban management, accompanied by increased urbanization and the resulting problems. The city is the place which drives citizens to maximum satisfaction and efficiency in the minimum time, replacement 
and cost. Thus, the organization of effective place with good shape provides citizens satisfaction. According to research conducted by the BES Institute on more than 1,000 public places in different countries of the world, the researchers found that the factor of accessibility is one of the most important cases in measuring the quality of public spaces and urban land use [16]. In this article, the land use site was analyzed according to the distributed criteria based on need and new urbanism features and principles can be applied in small and large enterprises. The Table (1) shows the benefits and the principles also for the residents concerning new urbanism

TABLE 1: the Principles of New Urbanism Theory. Source: [18].

\begin{tabular}{|c|c|}
\hline The Principle & The Description \\
\hline Walkability & $\begin{array}{l}\text { Places should be within a 10-minute walk from work or home and, Streets } \\
\text { should be free from cars. }\end{array}$ \\
\hline Connectivity & $\begin{array}{l}\text { Interconnected street grid network. A hierarchy of narrow streets, } \\
\text { boulevards and alleys are necessary and a high quality pedestrian network. }\end{array}$ \\
\hline $\begin{array}{l}\text { Mixed uses and } \\
\text { diversity }\end{array}$ & A mix of different sectors including retail and residential. \\
\hline Mixed houses & A range of types, sizes and prices in closer proximity. \\
\hline $\begin{array}{l}\text { Quality } \\
\text { architecture and } \\
\text { urban design }\end{array}$ & $\begin{array}{l}\text { The emphasis is on beauty, human comfort, creating sense of place. The } \\
\text { Human scale beautiful and architecture surrounded nourish of the human } \\
\text { spirit. }\end{array}$ \\
\hline $\begin{array}{l}\text { The Traditional } \\
\text { neighborhood } \\
\text { structure }\end{array}$ & $\begin{array}{l}\text { Public space at the center, Discernible edge and Centre. Transect planning } \\
\text { and highest densities at the Centre of town. }\end{array}$ \\
\hline Increased density & $\begin{array}{l}\text { Denser services, buildings, shops and residences, closer together for the ease } \\
\text { of walking. This can enables the more efficient use of resources and services. }\end{array}$ \\
\hline Smart transport & $\begin{array}{l}\text { A network of high-quality trains connect towns, cities, and neighborhoods } \\
\text { together. Pedestrian- designs that encourage a greater use of bicycles, } \\
\text { walking a rollerblades as daily transport. }\end{array}$ \\
\hline Sustainability & Development should have a less impact to the environment. \\
\hline The Quality of life & $\begin{array}{l}\text { Improving the urban environment to raise the living standards of its } \\
\text { residents. }\end{array}$ \\
\hline
\end{tabular}

Series of laws and conventions that regulate from the master plan of the architectural distribution, types of buildings and street were added for the above mentioned principles. [19] There are five documents (The Landscape, The Regulating Plan, the Architectural Regulations, the Urban Regulations and the Street Types Regulations). The above mentioned ten principles must be implementing to form the core of the new urban planning system, code and regulation on following three levels: We

1. Metropolis, city and town.

2. Neighborhood, district and the corridor.

3. Street, block and building. 
The new urbanism has, a very special emphasis on community feeling with a very strong social orientation. The new urbanites make a simple assumption of the social nature of man. It is assumed that the man has this idea is inspired, and a basic social need by American psychologist A. Maslow how put the social needs of human beings between the five of the most important needs.

Urban forms of urbanization has a new goal as the main re-discovery of the meaning of society, which is characterized in their cities before manufacturing. In this sense, emphasize the role of urban design in people's behavior.

\section{Methodology of research}

The methodology was based on the analytical descriptive approach and the survey methodology because of the nature of the work. The main thrust of the research applied the collection of theoretical bases and research recommendations through the library and documentation resources. The statistical community of this research involves the citizens of (The area of study (which was estimated the population of the study area in the old Karkh area, which included $(218,216,214,212,210)$ in the city of Baghdad about (18440) people now). The Sample size was (922). Sampling method in this study was a simple random sample. The figure (1) shows the location of the study area within the city of Baghdad.
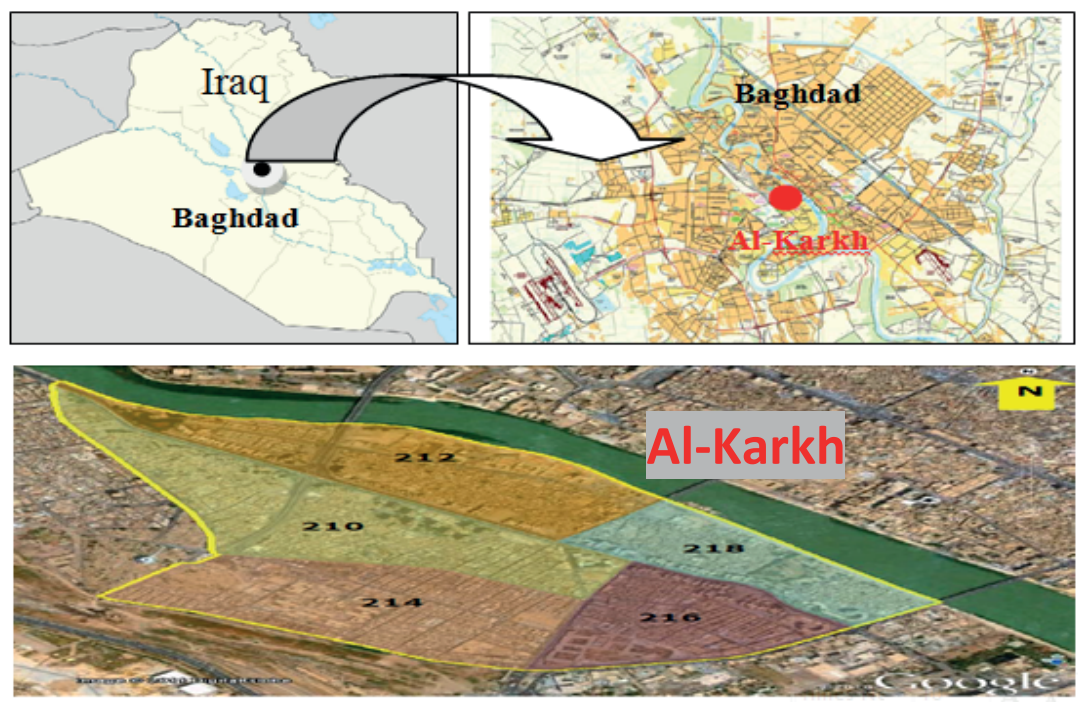

Figure 1: The location of the study area within the city of Baghdad. Source: Baghdad Municipality / Design Department. 


\section{Analysis of data}

According to Fig (2), among the total sample, 57.0 (6.2\%) of them were "20" years old or less, $676.0(73.3 \%)$ of them were between "21-40" years, $178.0(19.3 \%)$ of them were between "41-60" years and 11.0(1.2\%) were older than" 61 " years old, as a result, most of the participants were between " $21-40$ " years old and among all, 53.93\% of them were males and $46.07 \%$ were females. Fig (3)

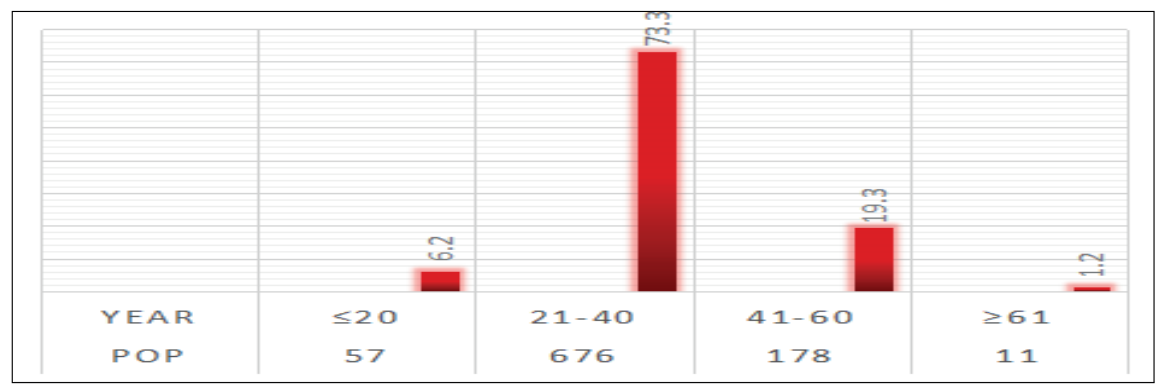

Figure 2: Age distribution of participants Source: The researcher depends on the field study.

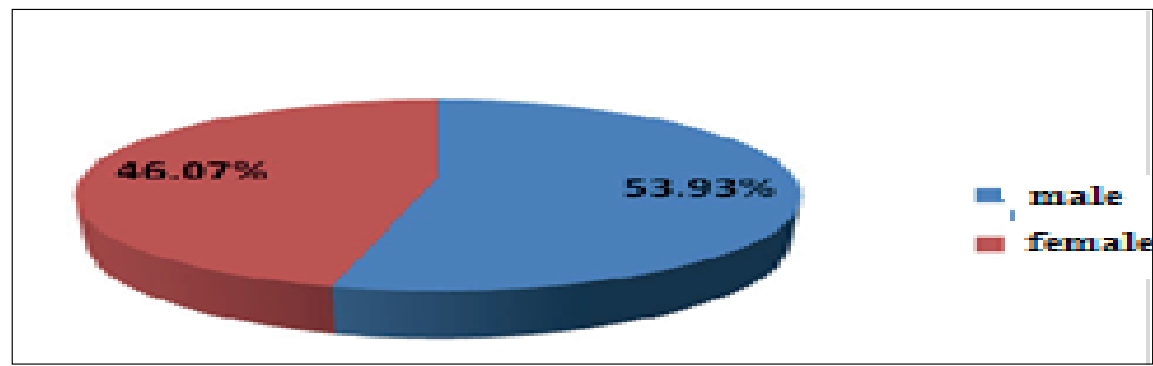

Figure 3: Sex distribution of participants Source: The researcher depends on the field study.

Oriented pedestrian on the development of walking and cycling paths, especially within the region was emphasized, which is a very special significance in the historic fabric of the region. In fact, strengthening the orientation of the pedestrian is the chief principle of the new urbanism, which is emphasized in the cities by making internal pathways that provide climate comfort for pedestrians. Another feature is to identify the most uses in walking distance of accessible and close to workplace and home. We can deal with this principle by setting active area centers and to identify a suitable place for the required uses so Fig (4) shows urban streets.

Communication can be achieved by identifying centers at the intersection of major multiple side roads, integrating the squares with the active ingredients such as bazaar, centers of areas and mosques, and a close relationship of the mosque with the other components of the city center and make a harmonious blend between communities and cities in the city, the city center spatially and physically, Fig(5a) shows Commercial, industrial and religious activities 


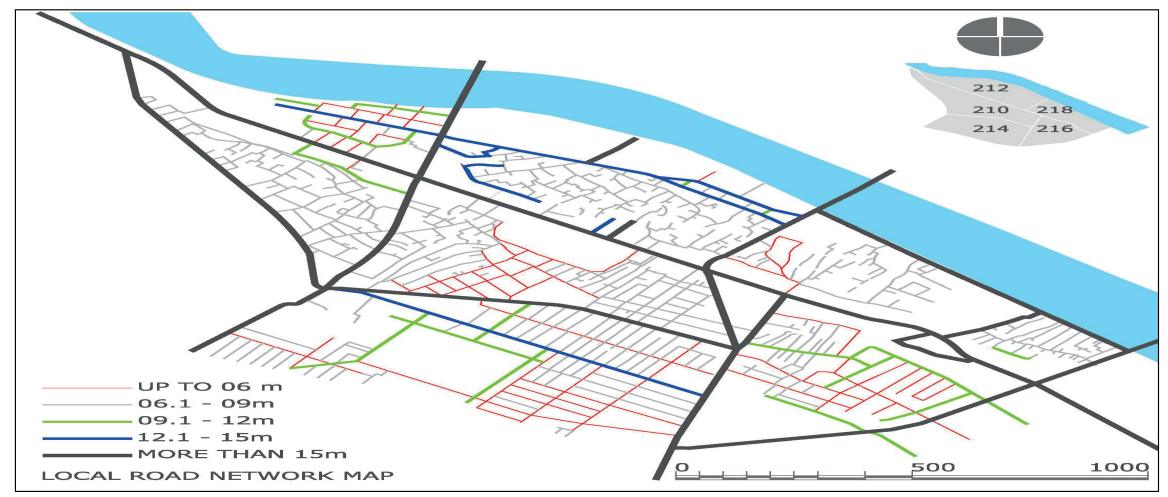

Figure 4: Urban streets Source: Baghdad Municipality / Design Department.

- Mix use Fig (5b) \& (6) and Table (II).

TABLE 2: Land use areas and percentages of occupancy for the study area. Source: Baghdad Municipality / Design Department.

\begin{tabular}{|c|c|c|}
\hline LAND USE & $\mathbf{H a}$ & $\%$ \\
\hline RESIDENTIAL & 23.58 & 10.76 \\
\hline M-STOREY RESIDENTIAL & 24.22 & 11.05 \\
\hline MIXED USE & 39.13 & 17.85 \\
\hline COMMERICIAL & 1.04 & 0.47 \\
\hline INDUSTRIAL & 2.23 & 1.02 \\
\hline EDUCATION & 7.46 & 3.40 \\
\hline HEALTH & 9.36 & 4.27 \\
\hline CULTURAL \& TOURISIM & 8.30 & 3.79 \\
\hline RELIGIOUS & 2.11 & 0.96 \\
\hline ADMIN.SECU. & 7.05 & 3.22 \\
\hline DIPLOMATIC & 2.65 & 1.21 \\
\hline YOUTH \& SPORT & 1.37 & 0.62 \\
\hline GREEN AREA & 5.95 & 2.72 \\
\hline GREEN BELT & 10.62 & 4.85 \\
\hline CEMETRY & 2.19 & 1.00 \\
\hline UTILITIES & 0.23 & 0.11 \\
\hline $\begin{array}{l}\text { ROAD NETWORK \& CAR } \\
\text { PARKINGS }\end{array}$ & 71.72 & 32.71 \\
\hline TOTAL & 219.23 & 100.00 \\
\hline
\end{tabular}

With regard to the analysis of the questionnaire data on the new urbanism principles was concluded that index satisfaction among the population of the studied area by putting in mind these principles. The communication was one of the principles. According to opinion of respondents, customer satisfaction index is at a middle level. The communication is effective in integrating activities clearly, so there must be homogeneity and connected between urban elements such as streets, external 

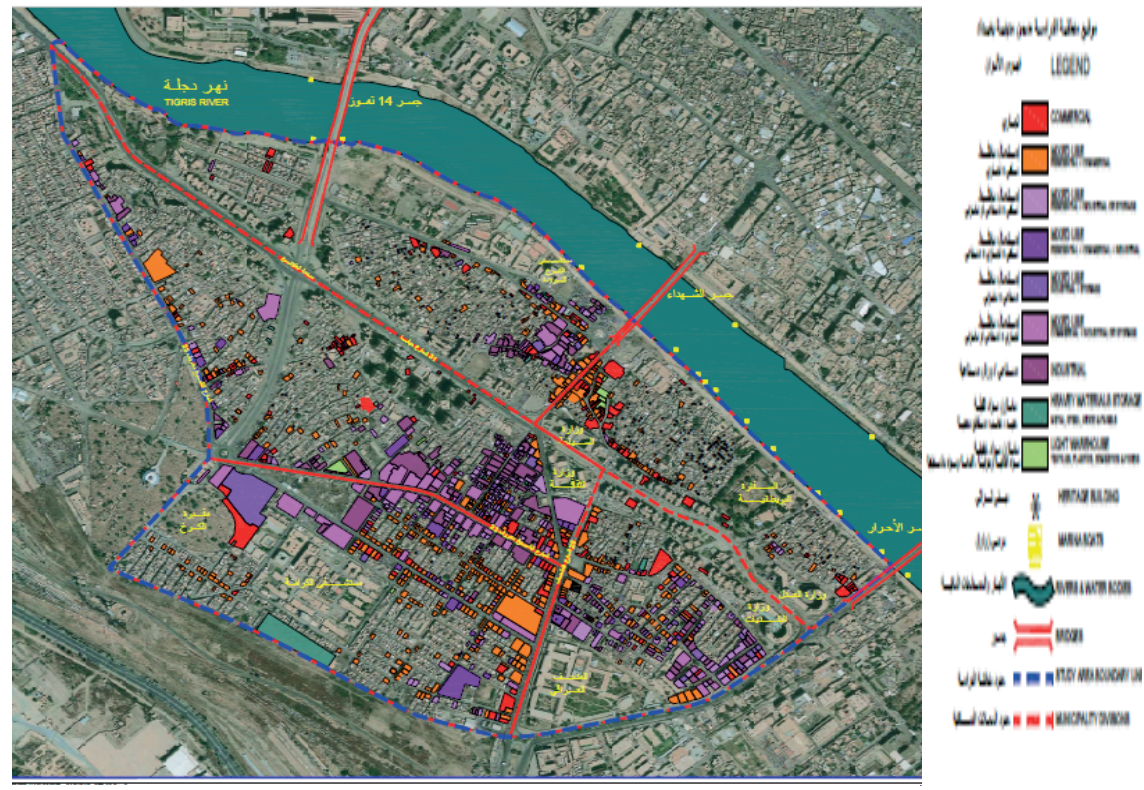

(a)
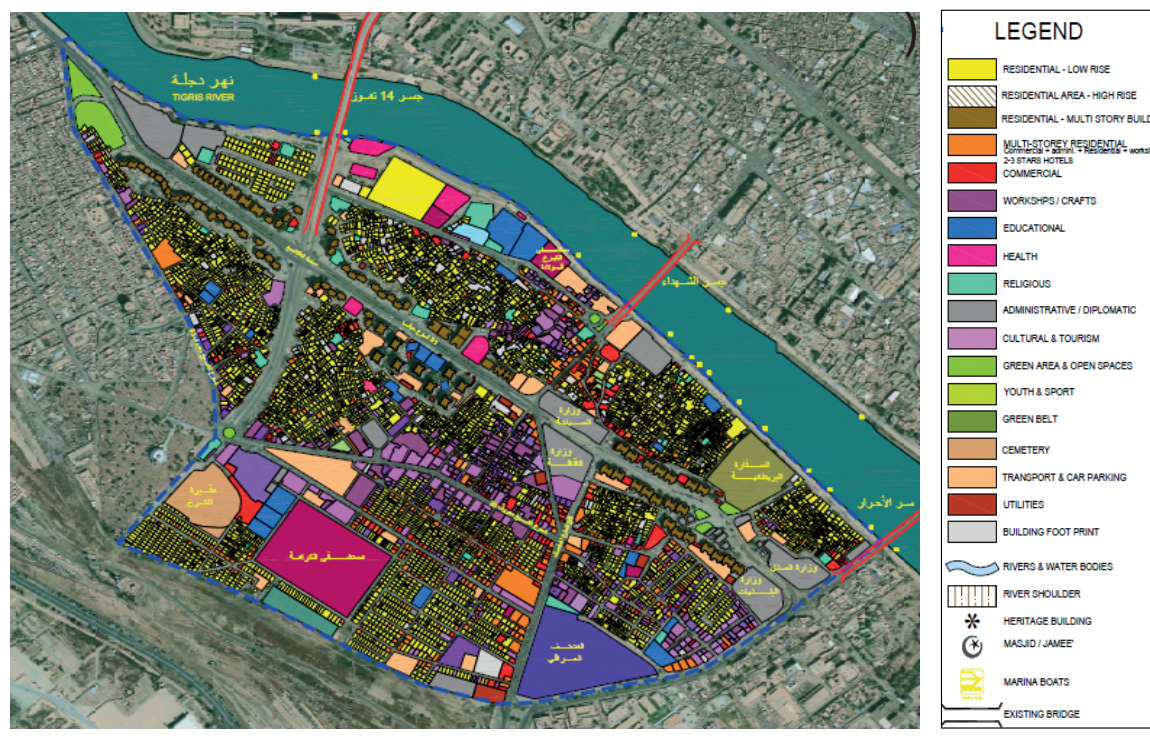

(b)

Figure 5: (a) Commercial, industrial and religious activities Source: Baghdad Municipality / Design Department. (b) land uses Source: Baghdad Municipality / Design Department.

spaces, and sidewalks but people are dissatisfied with the linkage of the elements in an area surveyed. Another principle of the new urbanism was the mixed use and public spaces and the promotion of green and preservation is another form of new urbanism too. Green spaces positively reduce pollution and affect mental health in the city, and therefore should increase the area of green space. There have been no initiatives to promote and expand the use of green space in the city. The population of the study area were not really satisfied with the green area per capita and access to these types' 


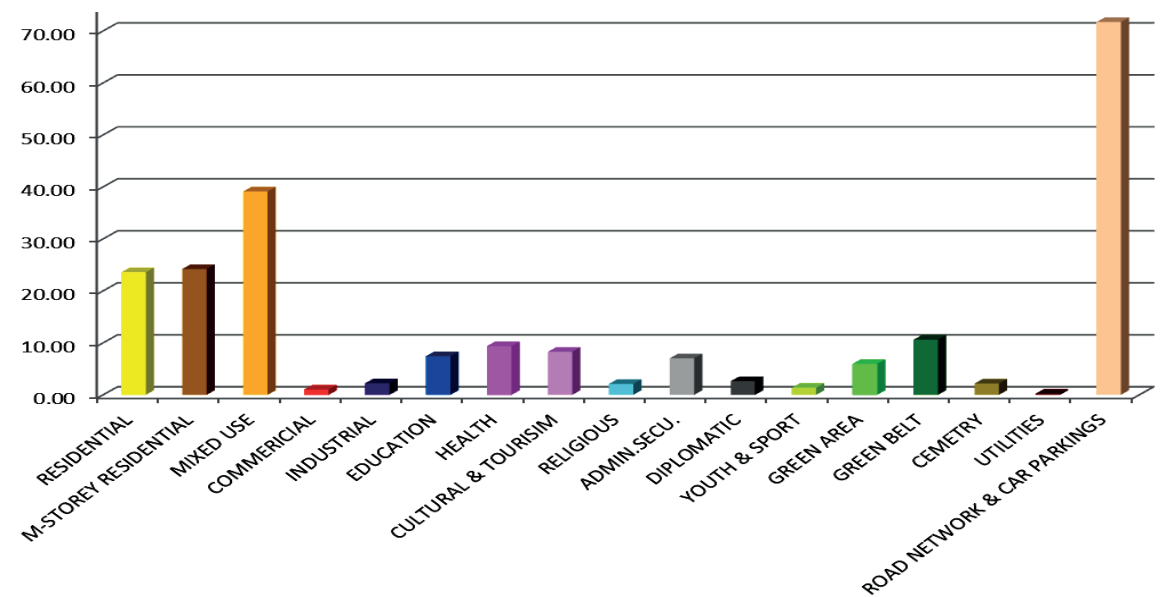

Figure 6: Land uses areas Source: Baghdad Municipality / Design Department.

of areas and with concern to the population density, so these areas were not provided. Public transport was also another challenge in the area. In this city public transport was not at the desired level, quantity, and responsible organizations didn't have neither a specific planning nor goal to improve the state of transport. Residential uses are in a condition which considered poor because of the existing homes did not correspond to the city population. People, specifically those with low incomes, cannot afford to pay for housing and their satisfaction was very low. The health in this city was not at the favorable situation because this usage is not distributed to the city and also citizens couldn't have access to this use. In the terms of spatial distribution of uses, human-oriented space should have the capacity to increase citizen ownership of the environment and to stimulate a good climate. In this way, peace is found and spiritual and social cooperation among citizen's increases. But in this city, the needs of people are not even considered and people don't have access for uses easily. They had to hike sometimes, so at the end, they were not satisfied.

To limit the dissatisfaction and satisfaction of urban environmental conditions, variables by respondents were chosen and the following "satisfaction index" which was developed by Hall, Yen. [18] was selected in this study.

$$
I s=\frac{(f s-f d)}{N}
$$

Were,

Is: The satisfaction index.

fs : The number of respondents satisfied.

$\mathrm{fd}$ : The number of respondents dissatisfied.

$\mathrm{N}$ : The total number of the respondents. 
Regarding this satisfaction index, it is $=+1$, which means the highest level of satisfaction is $=-1$, meaning higher Level of dissatisfaction.

TABLE 3: Satisfaction index of THE DIFFERENT variables uses in alKarkh city. Source: The researcher depends on the field study.

\begin{tabular}{|c|c|c|c|c|c|}
\hline \multirow[t]{2}{*}{ Is } & \multirow[t]{2}{*}{$\mathrm{N}$} & \multicolumn{3}{|c|}{ Groups } & \multirow[t]{2}{*}{ Variables } \\
\hline & & fd & *fa & fs & \\
\hline-1 & 922 & 922 & 0 & 0 & $\begin{array}{l}\text { Designing the passages } \\
\text { network in which provides } \\
\text { accessibility easily to the uses }\end{array}$ \\
\hline-0.64 & 922 & 675 & 162 & 85 & $\begin{array}{l}\text { population's satisfaction with } \\
\text { the way of access the uses }\end{array}$ \\
\hline-0.91 & 922 & 876 & 9 & 37 & $\begin{array}{l}\text { Easy accessibility to districts } \\
\text { and urban regions }\end{array}$ \\
\hline-0.92 & 922 & 857 & 56 & 9 & Easy accessibility to the uses \\
\hline-0.9 & 922 & 867 & 18 & 37 & $\begin{array}{l}\text { Suitable accessibility to the } \\
\text { urban uses }\end{array}$ \\
\hline-0.89 & 922 & 845 & 53 & 24 & $\begin{array}{l}\text { Satisfaction with locating the } \\
\text { uses }\end{array}$ \\
\hline-0.79 & 922 & 785 & 80 & 57 & $\begin{array}{l}\text { The Suitability of access } \\
\text { distance to uses in an urban } \\
\text { regions }\end{array}$ \\
\hline-0.78 & 922 & 801 & 39 & 82 & $\begin{array}{l}\text { The Suitability of use of } \\
\text { business in terms of } \\
\text { accessibility and distribution } \\
\text { over the city }\end{array}$ \\
\hline-0.56 & 922 & 678 & 82 & 162 & $\begin{array}{l}\text { The Satisfaction with access to } \\
\text { uses in AlKarkh }\end{array}$ \\
\hline
\end{tabular}

"fa: The number of acceptable respondents

With regard to the data in Table (III) in order to obtain the satisfaction index between the population of the study area, we subtracts a number of individuals was satisfied with the number of non-eligible individuals divided into the total number of respond. Using this formula, with regard to the issue, which obtain a number of this indicator for negative questionnaire questions, we can conclude that the level of satisfaction of the population of the study area with land use is very low and participants are not entirely satisfied with access to uses in the study area shows that with respect to a set of satisfaction indicators $(-1$ to +1$)$ and negative indexes obtained in this study,

\section{Discussion and the conclusion}

It was concluded from the data obtained from maps of GIS and questionnaires, that the comprehensive plan of the study area faced problems and obstacles that included, use of deleted parking spaces and side corridors in the city, low supply of main and unauthorized construction. Comparison between the current uses and the recommended 
level of approved uses indicates that many uses still not reaching the recommended level. This indicates that there was no the correct prediction of population, needs, and facilities; consultants have begun planning unknowingly and knowing the region based on the dispersed information and erroneous. After years, we are still far from intellectual planning.

The results of research showed that the more careful attention for human beings and their consideration in the context of urban planning and use should be among the priorities of the new urbanism. The new civilization is trying to create the conditions in which a person can live with higher quality and peacefully. In this regard, the population should provide transportation, should have access to walking and housing, should feel the reduction of accidents and risk, traffic costs, the city must be effective enough in improving public health. Providing the environment that urban populations can be the more effective is one of the most basic purposes of the new urbanism. Thus we can realize that the principles new urbanism in the city accompanied the satisfaction of population. If the distribution is based on the principles of new urbanism in the city of Karkh, the quality will certainly improve and change the urban environment. The major of spatial problems in a region stems from the lack of consideration of local principle and measures in the identification of land uses and absence of an integrated land-use system, and. It seems that attention to lack, constraints, and problems on the spatial structure of the area are essential in any planning. in Al Karkh, The land uses did not have an individual share. Therefore, the results of the research concluded that the incompatibility between the use of spaces, green, education, health and housing causes dissatisfaction among the people of AlKarkh city, Moreover, the planning between the uses must be more considered in order to balance uses and rebuild a city. The lack of mass-use communications in many parts of the city has caused some problems among citizens. We can conclude that the factor of accessibility is very important to measuring qualitative compliance with the use of urban land and the state of public space. The results of the research indicated also that the quality of the environment urban areas includes the economic, social, cultural, temporal conditions and spatial of urban conditions that determine the level of dissatisfaction and satisfaction to people. Increased material quality and appropriate capabilities are very effective in satisfy the people living in an urban area.

The good shape of the city is the model in which the basic of variables provide the highest satisfaction and efficiency with minimum replacement, time, and cost. So the organization with good shape and effective places provided good satisfaction to people. According to this research, land uses must distribute in the way that people do not have any difficulty in access those uses without wasting cost and time. In the 
other words, we cannot provide any favorable conditions in the cities without doing planning land use for people. This can do by assisting an expert and a specialist on all issues related to the city.

\section{Recommendations}

It has enabled us to identify the problems and constraints faced by the city by doing a detailed understanding, and then we made a meaningful plan in a long-term. It seems that with regard to the strategic location of the city, it requires viable plans like the urban strategic development plans. So we considered the following recommendations:

- The lack of existing consultants in cities is the one of the most serious problems, so providing the local office by a project consultant and by direct relationship between local office staff with local organizations and city administration, as well as the continuous relationship with the people necessary to reform preparation of the comprehensive plans.

- The green area must be increased in the studied area.

- Prevent concentration in cities centers, thereby reducing the traffic in heart of cities.

- Because of the high population densities during the day, the parking spaces must set up in cities center and some forecasts must be considered in the future plans for the use of the land under consideration for the gradual transfer of unnecessary places outside the city. Naked buildings on the ground should be banned at the level of high groundwater.

- The roles of urban linkages and connectivity in centers of areas must be considered through the main streets or corridors. The network of existing corridors and the expansion of narrow corridors should be modified.

- With regard to the physical, social, cultural, and economic situation of the region, as well as the dispersion and distribution of population, location of uses and activities, the physical divisions, in cities and the rehabilitation of its borders must be revised.

- Consensus should consider in the studies on be understanding the current situation and fieldwork of the land uses. Relevant information must apply to the development of the future of land-use plans and the kinds of recommended use of city that it isn't normally considered in the urban plan for the country; therefore, it is necessary to make the balance for the uses and to remove the imbalance. 
- The city area must be considered as the hub for public services in the region, and through the construction of a ground building with a different kind of function between floors and the public demand of the population, and the provision of free space. Important uses must separate to reduce the risks of large-scale fires. The sidewalks should be separated from the green road vehicles also.

- Public and private transport areas should be allocated to accelerate public transport and speed.

\section{References}

[1] Kening, s"Three domains of New Urbanism" Architect, 2003, p.25-26.

[2] Asgharzade, Sara,"The recommended principles of new urbanism in planning urban districts", The journal of the Housing and village environment, 29th year, No.130, 2010 p.p 50-63,

[3] Maleky, Saeed;"The spatial analysis of physical development pattern of Ilam city", Master thesis in the social and human sciences, Tabris University, 2000 p 67.

[4] Zhixin, H."First step quest of the New Urbanism in China-the new trend of community exploitation in suburbia. Tianjin: Tianjin University, 2004, p.4.

[5] Ziary, Keramatollah, urban land use planning, Yazd, Publication of Yazd University, first edition, 1999 p 98.

[6] Ebrahim zade, Isa; Bazrafshan, Javad \& Kazem Habibzade; analyzing and evaluating rural and small town land use in Iran by the means of GIS ( case study from Khoshrudpey Babol), urban and regional researches, second year, No.5, summer 2010 p 113.

[7] Talen, Emily" Design that enables diversity: the complications of a planning ideal", Journal of Planning Literature 20(3): 2006p 233-249.

[8] Sewell, John." The shape of the suburbs: understanding Toronto's sprawl. Toronto": University of Toronto Press. 2009 P43.

[9] Young, A "Land Resources; Now and For the Future". Cambridge University Press,1998, p 319.

[10] FAO (1998b). Aquaculture Production Statistics, 1987-1996. FAO, Rome. FAO Fisheries Circular No. 815, Rev. 10, 197 P.

[11] FAO "FESLM": "An international framework for evaluating sustainable land management", J. Dumanski, J \&. Smyth, A.J., (eds.). The world of Soil Resources Report no.73, Rome,1999b,. 74 P. 
[12] FAO "Guidelines for land-use planning", Soil Resources, Management and Conservation Service. FAO, Rome(1993).

[13] Al-Azawi, Hisham, Adnan "The Influence of Intellectual Change on Urban Patterns", unpublished doctoral thesis, To the Department of Architecture, University of Baghdad.1992 p12.

[14] Tabibian, Manuchehr; Aghmashe, Maryam; "localization of new urbanism theory in Qazvin city( case study from Punak town)", Proceedings of the urbanization and sustainable development, institution of the higher education of Mashad, 2013 p65.

[15] AlHabiby, Mohsen; Navid ,Mohammadreza, \& Tahsildar, Mahdy; "a description on principles and rules of native urbanization in relation with contemporary theories of urbanization",The journal of the Housing and village environment, No.135, fall 2011 P34.

[16] AlKhodaei, Zahra; AlKheiry, Ali," The quality of urban environment and its role on promoting satisfaction of citizens" , Journal of the social science, No.36, Spring 2009 p98.

[17] Stamatina Th. Rassia , Panos M Pardalos " Cities for Smart Environmental and Energy Futures",Impacts on Architecture and Technology , Springer -Verlag Berlin "Heidelberg, 2014, P(274).

[18] Hall., Yeh, S. H., \& Tan, S. L., Satisfaction of living condition, In S. H. Yen (Ed.), Public housing in Singapore. Singapore: Singapore University Press, 1975

[19] Robbins, Edward and El-Khoury, Rodolphe," the Shaping of the City. Studies in theory, history and urban design. London and New York: Routledge. 2004 P 219. 